\title{
Potential Study of Biomass in the Area of Cartagena (Spain) under the ENERING LIFE+ European Project
}

\author{
J. Serrano ${ }^{1}$, J. M. Paredes ${ }^{1}$, M. S. García-Cascales ${ }^{2}$, J. M. Sánchez-Lozano ${ }^{3}$, A. Molina-García ${ }^{4}$ \\ ${ }^{1}$ Área de Energía. Centro Tecnológico de la Energía y Medio Ambiente(CETENMA) \\ Polígono Industrial Cabezo Beaza, P6-13, Cartagena (Spain) \\ +34 968520361/968520134, e-mail: cetenma@cetenma.es \\ ${ }^{2}$ Departamento de Electrónica, Tecnología de Computadoras y Proyectos \\ +34968326574 socorro.garcia@ upct.es \\ ${ }^{3}$ Centro Universitario de la Defensa. Academia General del Aire \\ +34968189914 juanmi.sanchez@cud.upct.es \\ ${ }^{4}$ Departamento de Ingeniería Eléctrica. Campus Muralla del Mar, Universidad Politécnica de Cartagena \\ 30202 Cartagena (Spain) \\ +34968325462 angel.molina@ upct.es
}

\begin{abstract}
.
The ENERING LIFE + project is focused on demonstrating the possibilities of reduction of power demand and $\mathrm{CO}_{2}$ emissions in industrial parks, by applying environmental and economically feasible solutions in a real industrial environment. This proposal is based on buildings design, passive energy solutions for existing buildings and, mainly, the integration of local renewable resources to cover common necessities of installations in industrial parks and industries compensating/reducing $\mathrm{CO}_{2}$ emissions.
\end{abstract}

The project is located in the industrial area of "Los Camachos" (37.635781, -0.90384) in the city of Cartagena, Spain, where the company Diego Zamora SL has established its new facility dedicated to the production and storage of liquors. As a preliminary solution to decrease the power demand was proposed the use of autochthonous biomass from the nearby area to supply heat and cool (using absorption machine) within the manufacturer process. In this work, a methodology for the estimation of the quantity of biomass and its energy potential in the area of Cartagena is determined by using a GIS solution. Result allows us to optimize biomass supply and logistical issues at the project facilities.

\section{Keywords.}

Geographic Information System; Renewable Energies; gvSIG; Biomass.

\section{Introduction}

The main objective of the ENERING LIFE + (Ref. LIFEENV-11-ES-542) [1] is the demonstration of environmental and economically feasible solutions to reduce $\mathrm{CO}_{2}$ emissions in industrial parks. These solutions are based on industrial building design and adaptation of old buildings, passive energy solutions, renewable energies installations and the use of residual energy to cover electricity needs of common facilities around the industrial park and also the energy needs from other industries placed at the industrial park. They include not only individual solutions, but also management actions involving the whole industrial park.

The demonstrative project is located in the industrial area of "Los Camachos" (37.635781, -0.90384) in Cartagena, where the company Diego Zamora SL $[2,3]$ has established its new facility dedicated to the production and storage of liquor.

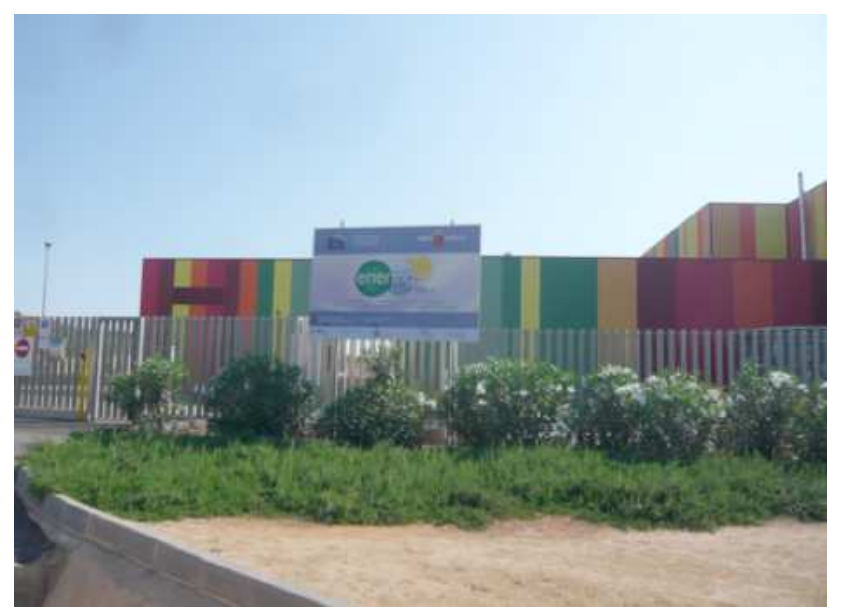

Fig. 1. ENERING+ Demonstration Site at Diego Zamora S.A. Plant (Los Camachos, Murcia) 
The production process of Diego Zamora in terms of energy demand can be divided into electricity demand (lighting, power, air conditioning) and cold and hot water needs in order to supply the specific requirements for the product maceration process.

The proposed solution covers most power demand points of the production process, providing part of the total electrical energy needs, part of cooling needs and the entire hot water requirements, from renewable energy sources located in the area nearby the industrial park. These renewable inputs have been chosen by the integration of a PV power plant $(100 \mathrm{kWp})$, a $500 \mathrm{~kW}$ biomass boiler covering completely the hot water needs of the production process as well as the hot water demand required from $312 \mathrm{~kW}$ absorption chiller producing the required cool water for the production process, product storage and air conditioning requirements [3].

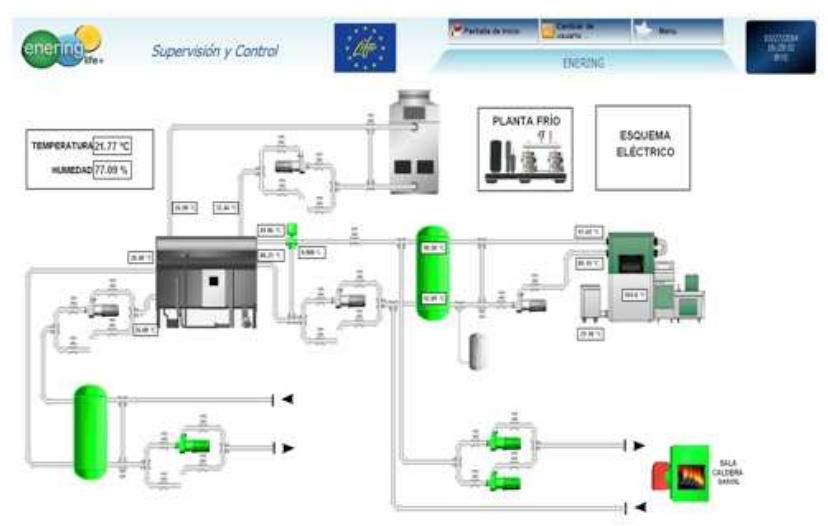

Fig. 2. Enering+. General process

As a complementary objective, energy surplus at the plant is transferred to other nearby industrial processes in the industrial area with similar energy needs

A detailed analysis of biomass resources in the area of Cartagena (Spain) is carried out by the authors to ensure the proper supply of biomass, avoiding any logistical issue. In this way, the area of Cartagena is a county of the Region of Murcia located in the southeast of Spain. It is divided into 7 municipalities: San Pedro del Pinatar, San Javier, Los Alcázares, Torre Pacheco, Cartagena, Fuente Alamo and La Unión. Nowadays, pruning of woody crops is being wasted in the area of Cartagena, since only some farmers use them as firewood for self-consumption and sell the rest to local people. Therefore, thousands of tons are normally left untreated and mostly burned in crop areas.

\section{Objectives}

The main objective of this paper is focused on providing a detailed investigation of the biomass energy resources, currently available in the area of Cartagena (Murcia, Spain). The specific objectives are the following:
1) To characterize the resources of crop grasses following agricultural criteria (woody crops).

2) To evaluate these resources and identify and quantify all the parameters that affect the availability of biomass resource and the economic viability of the supply chain, for Enering+ and similar projects in terms of biomass distribution and transportation cost

3) To obtain the cartography of crop grasses resources (woody crops) of Campo de Cartagena as a function of municipality and types of woody crops, by using Geographic Information Systems (GIS).

\section{Methodology.}

\section{A. Preliminary studies.}

The first step consists of the selection of information from existing spatial data layers or data bases, such as the National Forest Inventory III IFN Directorate General for Nature Conservation (DGCONA) [4], which can be directly used in the same cartography. Nonetheless the most significant information was provided by the Actual Vegetation Map [5], the National Habitat Mapping [6] the Crop and Areas Use Map (2001)[7], Regional Agricultural Statistics 2000 [8] DATABASE and the Renewable Energy Plan 2011-2020, IDAE.[9]

\section{B. Crops selection}

Once all the data have been collected, main crops are analysed in order to evaluate their potential as energy resource.

Table I and Figure 3 summarizes the surfaces occupied by the main crops and grassland in the area of Cartagena. (See Figure 1 and Table I) [7].

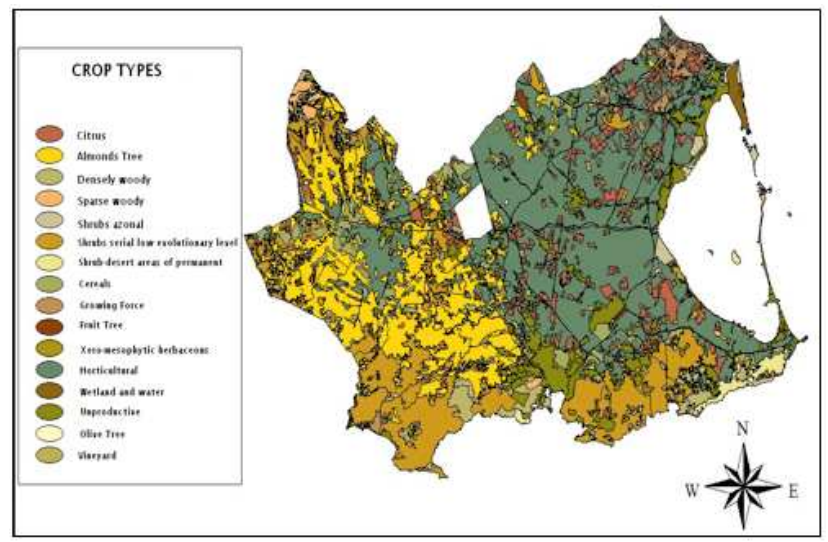

Fig. 3. Crop and grassland in the area of Cartagena (Spain). (Source: IMIDA [7], own elaboration). 
Table I. Distribution of grasses and crops by surface (Ha) in the area of Cartagena.

(Source: IMIDA[7], own elaboration).

\begin{tabular}{ccc}
\hline Grasses and Crops & Surface (Ha) & Surface (\%) \\
\hline $\begin{array}{c}\text { Grasses with densely } \\
\text { woody }\end{array}$ & $3.807,25$ & $1,93 \%$ \\
\hline $\begin{array}{c}\text { Grasses with sparse } \\
\text { woody }\end{array}$ & $1.695,31$ & $0,86 \%$ \\
$\begin{array}{c}\text { Shrub-desert areas of } \\
\text { permanent }\end{array}$ & $1.320,55$ & $0,67 \%$ \\
Heathy azonal & $1.578,98$ & $0,80 \%$ \\
$\begin{array}{c}\text { Shrubs serial low } \\
\text { evolutionary level }\end{array}$ & $35.372,94$ & $17,94 \%$ \\
$\begin{array}{c}\text { Xero-mesophytic } \\
\text { herbaceous perennials } \\
\text { and annuals } \\
\text { Cereals }\end{array}$ & 32,80 & $0,02 \%$ \\
\hline $\begin{array}{c}\text { Almond and mixed } \\
\text { plantings with other }\end{array}$ & $11.914,48$ & $6,04 \%$ \\
$\quad$ woody & $27.973,64$ & $14,19 \%$ \\
horticultural & $84.125,34$ & $42,67 \%$ \\
\hline Fruit & 585,88 & $0,30 \%$ \\
Citrus & $7.562,34$ & $3,84 \%$ \\
\hline Vineyards & 100,61 & $0,05 \%$ \\
\hline Olives Tree & 41,82 & $0,02 \%$ \\
\hline Growing Force & $2.440,34$ & $1,24 \%$ \\
\hline $\begin{array}{c}\text { unproductive } \\
\text { Wetland and water }\end{array}$ & $16.688,67$ & $8,46 \%$ \\
\hline TOTAL & $1.912,74$ & $0,97 \%$ \\
\hline $\mathbf{1 9 7 . 1 5 3 , 6 9}$ & $\mathbf{1 0 0 , 0 0 \%}$ \\
\hline
\end{tabular}

For this work, only wood crops were selected as potential resources. The selected crops were:

1) Citrus: rest of pruning, harvesting and excess pulp. The main species are: lemon, orange, mandarin and grapefruit.

2) Fruit: rest of pruning, crop surpluses and herbaceous layer. The main species are: peach, apricot, plum and pear.

3) Olive tree: Rest mainly pruning and grazing of the herbaceous layer.

4) Vineyard: grazing branches of the vine in autumn after harvest and grazing of the herbaceous layer in winter.

5) Almond tree: winter grazing of the herbaceous layer, pruning and shells. It also includes partnerships with other fruit of the almond in rain-fed, especially olive, carob, vineyards and apricot.

\section{Energetic Potential of Biomass}

To be able to calculate the biomass energy potential and carry out the relevant calculations, the pruning ratios of woody crops (MPP) and the pickup coefficients for seasonality of each crop (Cr) were taken into consideration together with the surface (S) and the potential biomass (Ppot). The annual availability biomass can be calculated as follows:

$$
B M(t / \text { year })=P_{p o t} \cdot S \cdot M P P \cdot C r
$$

Once these data are obtained and by using the Lower Heat Value (LHV) of each woody crop, found in the energy density table provided by IDAE in the document "Evaluation of the potential of biomass energy"[10], the energetic potential of each studied specie can be determined.

\section{Maps development}

The next step is the integration of all the data analyzed by using two GIS tools. On the one hand, the gvSIG software developed by the Department of Infrastructure and Transport of the Valencian Community and, on the other hand, the ArcVIEW software developed by ESRI. Using these tools, the collected information can be gathered in maps and tables that could be used to perform calculations in order to make assessment of the available biomass resources and their energy potential in the area of Cartagena.

\section{Results}

The first analysis consisted in analyzing the surface of the selected crops for each municipality of the area of Cartagena. This analysis allows performing an independent and graphic analysis of the amount of biomass available in the areas nearby Enering+ demonstration plant.

Table 1. Woody crops, areas for municipalities. Source: own elaboration

\begin{tabular}{|c|c|c|c|c|}
\hline Municipalites & Crop & $\begin{array}{c}\text { Surface } \\
\text { (Ha) }\end{array}$ & $\begin{array}{c}\text { Surface } \\
(\%)\end{array}$ & $\begin{array}{c}\text { Total } \\
\text { Woody } \\
\text { Crop(Ha) }\end{array}$ \\
\hline S. P. Pinatar & Citrus & 367,34 & $0,99 \%$ & 367.34 \\
\hline San Javier & Almonds & 70,17 & $0,19 \%$ & \multirow{3}{*}{$1.898,89$} \\
\hline San Javier & Cirius & 1815,44 & $4,92 \%$ & \\
\hline San Javier & Fruit Tree & 13,28 & $0,04 \%$ & \\
\hline $\begin{array}{c}\text { Los } \\
\text { Alcázares }\end{array}$ & Cirius & 120,98 & $0,33 \%$ & 120,98 \\
\hline T. Pacheco & Almonds & 976,53 & $2,64 \%$ & \multirow{5}{*}{$3.178,20$} \\
\hline T. Pacheco & Citrus & 1846,16 & $5,00 \%$ & \\
\hline T. Pacheco & Fruit Tree & 293,89 & $0,80 \%$ & \\
\hline T. Pacheco & Olive Tree & 28,33 & $0,08 \%$ & \\
\hline T. Pacheco & Vineyards & 33,29 & $0,09 \%$ & \\
\hline La Unión & Almonds & 30,21 & $0,08 \%$ & \multirow{2}{*}{135,63} \\
\hline La Unión & Citrus & 105,42 & $0,29 \%$ & \\
\hline Cartagena & Almonds & 10668,07 & $28,88 \%$ & \multirow{5}{*}{$13.704,50$} \\
\hline Cartagena & Citrus & 2778,84 & $7,52 \%$ & \\
\hline Cartagena & Fruit Tree & 183,65 & $0,50 \%$ & \\
\hline Cartagena & Olive Tree & 41,82 & $0,11 \%$ & \\
\hline Cartagena & Vineyards & 32,13 & $0,09 \%$ & \\
\hline F. Álamo & Almonds & 16422,88 & $44,46 \%$ & \multirow{5}{*}{$17.530,67$} \\
\hline F. Álamo & Citrus & 964,05 & $2,61 \%$ & \\
\hline F. Álamo & Fruit Tree & 95,07 & $0,26 \%$ & \\
\hline F. Álamo & Olive Tree & 13,48 & $0,04 \%$ & \\
\hline F. Álamo & Vineyards & 35,19 & $0,10 \%$ & \\
\hline TOTAL & & $36.936,21$ & $100,00 \%$ & $36.936,21$ \\
\hline
\end{tabular}


In Table 3 the energy potential of the different municipalities of the area of Cartagena is detailed. It can also be observed graphically in Figure 3 .

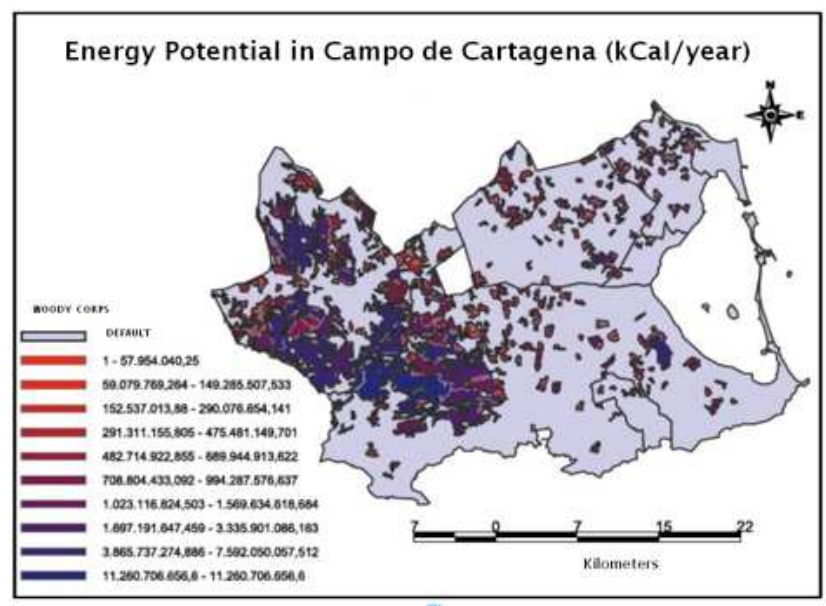

Fig. 4. Energy potential of woody crops in the area of Cartagena kcal / year (Source: own elaboration).

Table 3. Summary of the energy potential of tree crops in the municipalities of the area of Cartagena (Source: Author).

\begin{tabular}{ccc}
\hline Municipality & Surface $(\mathbf{H a})$ & $\begin{array}{c}\text { Energy Potential } \\
(\mathbf{M J} / \mathbf{y r})\end{array}$ \\
\hline S. P. Pinatar & 367,34 & $23.663 .694,62$ \\
San Javier & $1.898,89$ & $118.408 .164,35$ \\
Los Alcázares & 120,98 & $7.793 .218,98$ \\
Torre Pacheco & $3.178,20$ & $142.941 .758,36$ \\
La Unión & 135,63 & $7.304 .540,60$ \\
Cartagena & $13.662,68$ & $364.997 .640,74$ \\
Fuente Álamo & $17.530,67$ & $344.233 .521,39$ \\
\hline Total & $\mathbf{3 6 . 8 9 4 , 3 9}$ & $\mathbf{1 . 0 0 9 . 3 4 2 . 5 3 9 , 0 3}$ \\
\hline
\end{tabular}

\section{Conclusion}

This paper presents an estimation of the biomass resource available nearby the ENERING LIFE+ project demonstration site and the methodology developed to carry out this analysis. The developed method aims at the evaluation of the geographical distribution of biomass potential with and integrated approach that estimates the availability of biomass resource and the energy that can be extracted from it.

The spatial distribution of main crops is analysed using a GIS which constitutes the basis for the estimation and presentation of the available biomass potential.

A GIS is a useful tool and provides the means for identifying and quantifying all the parameters that affect the availability of biomass resource and the economic viability of the supply chain, for Enering+ and similar projects in terms of biomass distribution and transportation cost.

With the obtained results, it can be ensured the availability of enough residual biomass to supply the demand of the facilities of Enering+ to cover the described heat and cooling needs of Diego Zamora.

\section{Acknowledgement}

This work was supported with funds from the European LIFE + program by the project (LIFE-ENV-11-ES-542) and thank to all partners INFO, CETENMA, CTCON, COIIRM, UPCT project and the company DIEGO Zamora S.A.[2]

\section{References}

[1] ENERING LIFE+ official website. Available from: http://www.eneringlife.eu.

[2] Grupo Zamora S.A.; Available from: http://www.diegozamora.es.

[3] M. S. García-Cascales, A.M.-G., A. Ortuño, R. Martínez-Sánchez, Proyecto demostrativo de aprovechamiento de los recursos renovables locales en procesos industriales: ENERING LIFE+, in XVIII Congreso Internacional de Dirección e Ingeniería de Proyectos. Alcañíz (Teruel) 2014. (in Spanish)

[4] Dirección General para la Conservación de la Naturaleza (DGCONA), Inventario Forestal Nacional III IFN. 2012. (in Spanish)

[5] Alcaraz, A., Libro de Pastos, Mapa de Vegetación Actual. 2000. (in Spanish)

[6] 92/43/CEE, D., Cartografía Nacional de Hábitat. 2001. (in Spanish)

[7] IMIDA, Mapa de Cultivos y Aprovechamientos. 2001.

[8] CARM. Estadística Agraria de la Región de Murcia. 2000; Available from: https://www.carm.es/. (in Spanish)

[9] IDAE (2011) Plan de Energías Renovables 20112020. (in Spanish)

[10] IDAE, Evaluación del potencial de energía de la biomasa. 2011. (in Spanish) 